RESEARCH ARTICLE

\title{
From protest to progress through partnership with students: Being Human in STEM (HSTEM)
}

\author{
Sarah L. Bunnell ${ }^{1}$, Megan B. Lyster ${ }^{1}$, Kristen B. Greenland ${ }^{4}$, Gabrielle Mayer ${ }^{2}$, Kristen \\ Gardner $^{1}$, Tanya Leise ${ }^{1}$, Thea Kristensen ${ }^{1}$, Emma Ryan ${ }^{3}$, Richmond Ampiah-Bonney ${ }^{1}$, *Sheila S. \\ Jaswal $^{1}$ \\ ${ }^{1}$ Amherst College, U.S.A. \\ ${ }^{2}$ New York University Grossman School of Medicine \\ ${ }^{3}$ University of Washington School of Medicine \\ UUniversity of California, Berkeley \\ Contact: sjaswal@amherst.edu
}

\section{ABSTRACT}

In Fall 2015, Amherst College students held a four-day sit-in in unity with student protests occurring all over the United States highlighting barriers to inclusion of underrepresented and marginalized students. Following appeals for action, students partnered with faculty and staff in science, technology, engineering, and mathematics (STEM) to develop the Being Human in STEM (HSTEM) Initiative. HSTEM involves exploring past diversity and inclusion efforts in STEM, sharing one's own experiences in STEM with others, and developing student-driven projects to improve belonging in STEM. In this student, faculty, and staff co-authored paper, we describe the origin of HSTEM; share student, faculty, and staff reflections on our experiences with HSTEM; and present two inquiry projects examining HSTEM impact. We discuss lessons learned and recommendations for diversity and inclusion efforts in higher education, both in and beyond STEM, emphasizing the power of an initiative that was originated by and remains driven by student partners.

\section{KEYWORDS}

diversity, equity, inclusion, STEM, students-as-partners

Institutions of higher learning are experiencing more pressure than ever before to educate a diverse student body for a wide range of careers and life paths (e.g., Espinosa et al., 2019; Witham et al., 2015). Engaging with this challenge requires grappling with how power 
and privilege shape the structure of curriculums, the voices that are represented and unseen in curriculums, and the goals of higher education. Although many institutions seek to support diverse student groups through co-curricular initiatives and structures, approaches that merely adopt "wrap-around" co-curricular inclusion efforts while maintaining standard curricular and departmental structures and hierarchies can be limited in impact (e.g., Estrada et al., 2016; Mayhew et al., 2005; Schneider, 2014). Additionally, institutional efforts that do not incorporate student perspectives, goals, and values can not only impede progress but may be counterproductive to inclusivity (e.g., Bridges et al., 2005; Chickering \& Gamson, 1987; Matthews et al., 2018), as they can further intensify power structures and silence student perspectives.

In the United States and elsewhere, the challenges and opportunities for partnering with students in science, technology, engineering, and mathematics (STEM) education are particularly acute. In our national context, White and Asian-American students are overrepresented in the undergraduate and graduate STEM disciplines, and male students dramatically outnumber female students in these disciplines, according to the National Science Foundation (NSF) and National Center for Science and Engineering Statistics (NCSES) (2019) special report, Women, Minorities, and Persons with Disabilities in Science and Engineering. Indeed, the NSF and NCSES report indicates that $40 \%$ of Black students and $20 \%$ of Latino students who declare an intent to earn an undergraduate degree in the natural sciences do not go on to earn natural science degrees; in contrast, the comparable rates for White students and Asian students are $1.5 \%$ and $7 \%$, respectively. As such, students in the U.S. educational context are generally classified as members of an underrepresented minority if they identify as nonWhite or non-Asian.

Both structural and psychological factors contribute to these imbalances between majority (White and Asian) and underrepresented, minority (non-White or non-Asian) rates of STEM degree completion in the United States. At a systems level, differential higher educational preparation between majority and minority students is largely attributable to varying kindergarten through Grade 12 school financial resources, which in turn impacts textbook availability, laboratory materials, and instructor preparation levels (May \& Chubin, 2013). Additionally, when underrepresented minorities (URMs) enter STEM training programs, their persistence in STEM, operationally defined as the percentage of students declaring an intention to major in a STEM discipline who then go on to earn a degree in STEM and/or who pursue additional training post-graduation in the health professions (Estrada et al., 2016; Miller \& Kimmel, 2012) is much lower than that of their majority counterparts (Higher Education Research Institute, 2010; Ong et al., 2011). Further evidence suggests that URMS are at high risk of stereotype threat: reminders of their group membership, coupled with challenging educational experiences, can lead to an increased sense that one does not belong in the field and/or that one is not likely to be successful in its pursuit (Appel et al., 2011; Aronson et al., 1998; Beasley \& Fischer, 2012; Wang \& Degol, 2017). The lack of diversity among faculty in STEM higher education departments further escalates these tensions by creating visual 
reminders of a lack of belonging for non-majority students (Hermann et al., 2016; Espinosa, 2011). Important for understanding this work is the conceptualization of belonging. While earlier psychological work in attachment theory defines belonging as an internalized need for close and positive connections to others (e.g., Ainsworth, 1989; Baumeister \& Leary, 1995), more recent work recognizes that a sense of belonging truly emerges only when those positive relationships result in a feeling of being joined together in a unified community (Ahmed, 2012; Lambert et al., 2013). Thus, factors such as limited presence of non-White and non-Asian scientists, differential educational preparation, and stereotype threat jointly contribute to underrepresented minority students feeling as though they do not fit in, or belong, in STEM learning spaces.

More broadly, the nature of scientific inquiry itself may make STEM an intrinsically challenging space to diversify because of the widely held belief that science is an objective enterprise and thus personal attributes and identities should not factor into the scientific process. This type of environment can serve to dissociate individual development from development as a scientist and convey to students that struggle and individual differences are markers of ineptitude (Gurin et al., 2004; Kets \& Sandroni, 2016). Rather than emphasizing the objective nature of STEM, it has become clear that learning from, partnering with, and highlighting the lived, subjective experiences of students in the classroom is a potentially powerful step towards inclusive education (die Bie et al., 2019; Cook-Sather, 2015; 2018), and the approach of student partnership may be particularly well suited to addressing the challenges outlined above related to inclusive education in STEM.

\section{Other institutional efforts towards inclusive STEM education}

Colleges and universities have undertaken great efforts to support URM students in the STEM disciplines. Many of these institutions have focused on faculty development programs and pedagogical training in order to increase faculty members' use and awareness of the import of inclusive teaching strategies (e.g., Dewsbury \& Brame, 2019; McNair, 2016; Penner, 2018; Tanner, 2013). Other institutions have worked to enhance underrepresented students' academic skills and the supports provided to these students, such as group study sessions focused on complex problems (e.g., Treisman, 1992) and expanded opportunities for training, mentorship, and cohort-building (see the Meyerhoff Scholars Program at the University of Maryland, Baltimore County; Hrabowski, 2019). Finally, faculty at other institutions have developed courses aimed at raising students' awareness of the challenges and ethical issues related to diversity, equity, and inclusion in the natural sciences as a component of their undergraduate science curriculum (e.g., Hudgings \& Dalton, 2019; Reese, 2020). While many of these approaches provide documented improvements in underrepresented students' retention in STEM, in this paper we discuss our alternative approach-one which arose from a moment of campus conflict and reckoning, that has been developed through intensive partnership with students, and results in student-led action projects to increase all students' abilities to thrive in STEM. Rather than developing top-down institutional programs that do not directly partner 
with students to co-design aspects of their educational experience, student partnership is at the core of our approach, called "Being Human in STEM." This program, and its origin, is described below.

\section{Amherst College context}

For the past several decades, efforts to diversify the student bodies of colleges and universities across the country have expanded (Gurin et al., 2002; Hussar \& Bailey, 2018). Amherst College, a small liberal arts college in the United States, was founded in 1821 to educate male students for the ministry. Since then, this four-year undergraduate institution has evolved into a highly regarded college, enrolling about 1,850 students on a residential campus in western Massachusetts. Despite its long history, efforts to diversify the student body are relatively recent. It was not until 1974 that the Board of Trustees voted to make the college coeducational; Amherst now enrolls 50\% women. Beyond diversification of the student body based on sex, the college has more recently enacted significant measures to become one of the most racially, ethnically, and socio-economically diverse colleges in the country (see Figure 1). Under the leadership of former College President Tony Marx, all student loans were replaced with scholarship packages, such that students do not graduate with college debt, and needblind financial aid policies were expanded to international students. These practices have led to an all-time high enrollment of underrepresented minorities and first-generation and lowincome students. 
Figure 1. Breakdown of student enrollment at Amherst College according to race/ethnicity from 1977-2017.

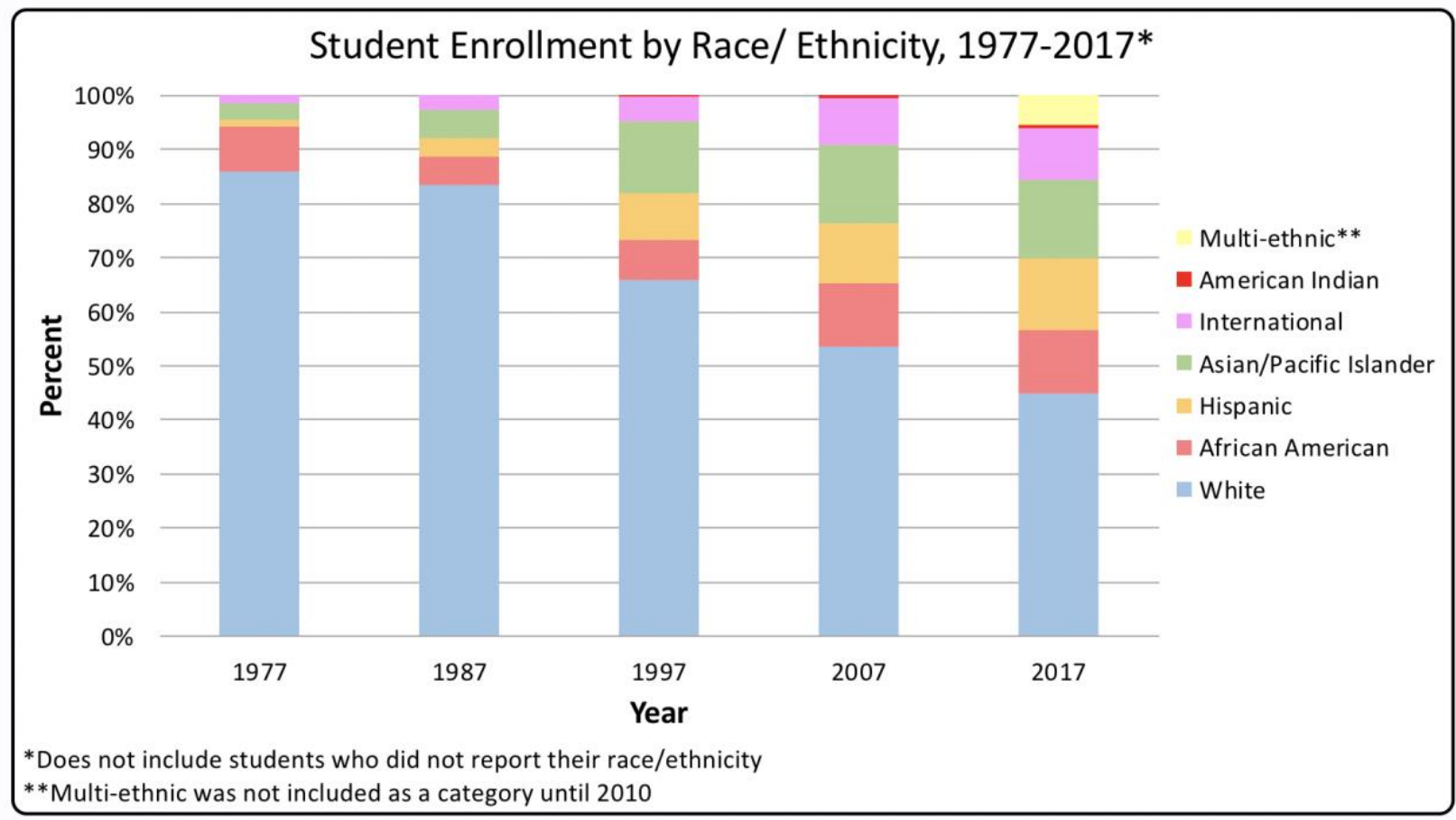

Success in opening access to qualified students from all backgrounds, however, outpaced the institution's ability to ensure that academic spaces were truly inclusive; the expectation that the structures and norms that had supported a homogenous student body in thriving, belonging, and succeeding could remain unchanged proved unrealistic. In November 2015, these tensions came to a head. During a Black Lives Matter protest on campus, organized by three Black female students, underrepresented minority students began sharing stories of their experiences of exclusion. What had been intended as an hour-long sit-in rapidly expanded into a multi-day occupation of the campus library; this event became known as the "Amherst Uprising." Over four days, the Amherst College community bore witness to the candid and often painful testimonies of marginalized students. Their frustration, anger, and hurt spurred a transformative moment of reckoning for the college at large (Jaswal, 2019). Moreover, the uprising prompted many members of the community to undergo self-reflection to critically assess their own personal contributions to equity and inclusion at the college. Many of the initiatives precipitated by the Amherst Uprising have continued to effect change on campus to this day. The Being Human in STEM Initiative (HSTEM), one of the results of the Uprising, is described here. 


\section{Students as Partners: A framework for progress towards inclusive STEM education}

Addressing the challenges brought forward through the Amherst Uprising in a productive manner required true partnership between faculty, staff, and students. It is important to note that while the college became co-educational in 1975, the first tenure-track female professor had only started a decade before (Dr. Rose Olver, in 1962). The faculty and instructional staff were typically educated in higher educational systems and structures that were still relatively non-diverse. As such, understanding the challenges that underrepresented students face and developing a positive direction for the college's curriculum going forward required authentic partnership and an openness to listening, learning, and collaborating.

When we engage students as partners, we increase students' active and authentic engagement with their learning (Bovill, 2017; Bovill et al., 2011, 2016; Cook-Sather \& Abbot, 2016; Matthews, 2017). In a partnership framework, we create space for uncovering bias and misunderstandings. When faculty, staff, and students work together as co-learners, they must depend upon one another, trust one another, and grant one another the agency to contribute meaningfully (Acai et al., 2017; Cook-Sather, 2018). The Students-as-Partners model, then, stands in stark contrast to the standard, top-down model of higher education which does not address the institutional and curricular structures which serve to maintain inequity (BlochShulman \& Castor, 2015; Bovill et al., 2016). It was only through disrupting these structures, we believed, that Amherst College could learn from the student experience and make progress.

As described by Healey, Flint, and Harrington (2014), Students-as-Partners models can operate in any of the following domains: (a) learning, teaching, and assessment; (b) curricular design and pedagogic consultancy; (c) subject-based research and inquiry; and (d) scholarship of teaching and learning. The HSTEM model includes aspects of all four components of student partnership. The HSTEM course includes subject-based research with students on the topic of diversity and inclusion in STEM. In addition to partnering with enrolled students to shape regular aspects of the course by, for example, adding discussion topics, choosing project foci, and designing the community sharing events, faculty and staff facilitators of the HSTEM course frequently partner with post-baccalaureate students in co-leading and refining the course over the semester. Students also partner with faculty and staff on scholarship of teaching and learning projects, and all students engage in action projects to enact change in an aspect of inclusion or diversity in STEM.

One of the action projects emerging from the HSTEM course is a student-authored handbook of suggested inclusive curricular practices (http://www.beinghumaninstem.com/inclusive-curricular-resources.html), which aligns with the second domain of Healey, Flint, and Harrison's (2014) Students-as-Partners model, curricular design and pedagogic consultancy. This document, which has undergone additional revisions and expansions by faculty and staff, incorporates recommendations from students' classroom experiences and the broader pedagogical research on inclusive teaching. The 30page HSTEM Inclusive Curricular Practices Handbook is one of the most impactful outcomes of the HSTEM student partnership course model at Amherst College to date, as it is shared 
annually with all new STEM faculty and guides the focus for STEM faculty and staff as they integrate and refine inclusive practices in their teaching. We evaluated the impact of a subset of these practices on student learning in multiple laboratory sections of an introductory science course; the results of that analysis are presented in detail later in this paper.

\section{Our approach: The Being Human in STEM (HSTEM) course}

The original HSTEM course was conceived in discussions between Dr. Sheila Jaswal and students from her biochemistry course during and after the Amherst Uprising. Following email appeals by a female Black neuroscience major and a gender non-binary White biochemistry and biophysics major, every STEM department had issued a public letter of support, applauding students for speaking up and pledging to do better. The students and Dr. Jaswal recognized a need to seize this unique moment of campus community and commitment to improvement across STEM departments. As scientists, they also wanted to ground these individual stories of exclusion in the academic literature. Finally, it was important that these investigations were leveraged into action. Throughout, it was clear that centering the student voice in all of this work would be critical for its success. In spring 2016, therefore, Dr. Jaswal and nine students engaged in a student-driven, student-centered independent study course entitled "Being Human in STEM." The aim of the course was simple: to understand how humanity and science intersect on campus and beyond. The course has now been taught eight times and is included in the course catalog. In all academic semester course offerings, students enrolled in the course earn course credit towards graduation, while post-baccalaureate student fellows are paid for their work. In early iterations, faculty and staff co-facilitators taught the course as an overload to their other duties at the college without additional compensation; for the most recent offering, faculty did receive teaching credit. Although specifics have varied across semesters, including whether the course is offered as an independent study, a two-week intensive summer course, or a semester-long course, each HSTEM offering consists of four phases (see Figure 2). 
Figure 2. The four key phases of the HSTEM course model

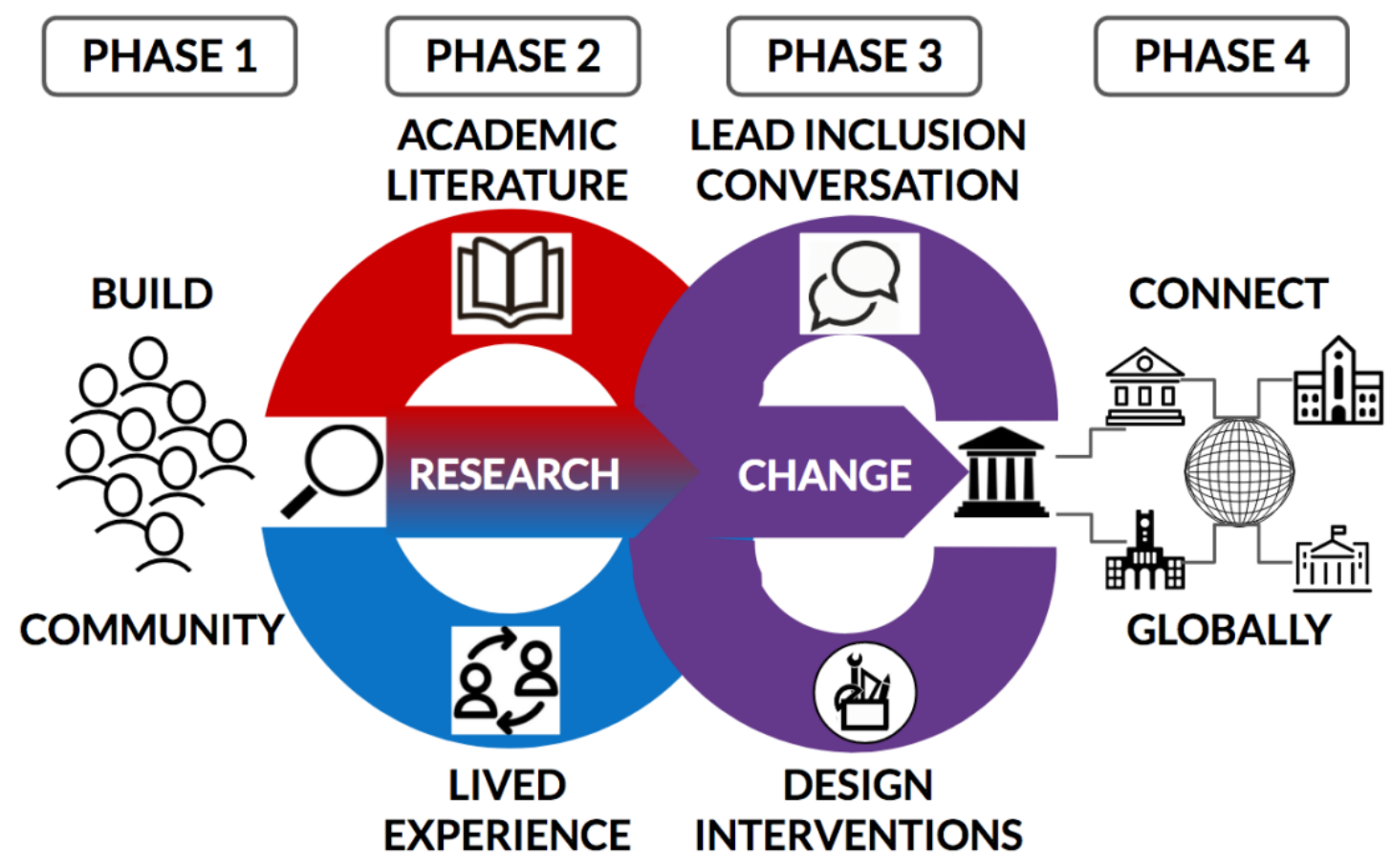

Phase 1: Intentional community building

All participants in the course (enrolled students and faculty, staff, and postbaccalaureate fellow co-facilitators) engage in activities designed to build trust, establish community norms, and share their own experiences in STEM. This phase is critical to the success of the course, as these activities attempt to democratize the classroom through shared vulnerability and, in turn, provide a solid foundation from which to engage in difficult conversations and imagine creative possibilities for addressing issues in STEM education.

Phase 2: Parallel research into the local lived STEM experience and academic literature

Participants discuss shared readings on diversity and inclusion in STEM and complete written reflections. Concurrently, participants broaden their understanding of the lived experiences of other students, faculty, and staff at their institution through interviews, social events, and panel presentations. To learn more about the student interview portion of the course, and to read the summary that our pioneers constructed as a result of this work, please visit http://www.beinghumaninstem.com/the-interview-project.html.

Phase 3: Focus on local community change through intervention design and campus conversations

Phase 3 represents a shift to a student-directed process of creating change in the campus community. Participants identify compelling themes and patterns from the 
foundational research conducted in Phase 2 and design local interventions. To sustain project impact over time, participants have typically chosen a project topic under four broad categories: (a) expanding/deepening HSTEM interventions on campus, (b) documenting/archiving HSTEM story and artifacts, (c) engaging stakeholders beyond Amherst College, and (d) supporting engagement of elementary-aged children in STEM. Full project descriptions and artifacts can be found at http://www.beinghumaninstem.com/about1.html. This phase also contributes to shaping the ongoing campus conversation around inclusion, as project groups solicit feedback from stakeholders and present their work to campus community members at the end of the semester.

\section{Phase 4: Connect with others participating in inclusive STEM initiatives}

Each semester, participants present their intervention designs and findings with participants in related courses at other institutions, including Brown University, Yale University, and Williams and Mount Holyoke Colleges. This serves as both a moment of shared accountability as well as an opportunity to learn and be inspired by the projects being developed elsewhere. Students have also presented their work at regional and national conferences (e.g., Bohan et al., 2017; Bunnell et al., 2019).

\section{The Being Human in STEM collaborative team}

Developing, implementing, assessing, and making public the outcomes of the Being Human in STEM Initiative has drawn on and continues to draw on the contributions of many individuals. These individuals are described in Table 1, using pseudonyms. "Co-facilitators" have participated in the design and implementation of one or more HSTEM courses during the academic year or during the two-week summer session. The term "pioneers" references students and the faculty member who initially co-designed the course in Spring 2016, while "post-baccalaureate fellows" are students who graduated from the college and were then employed by the college, providing part-time support for the HSTEM Initiative. Finally, as this work lays bare the critical roles of intersectional identities in our work, some aspects of our identities are also presented here.

Table 1. Overview of HSTEM contributors

\begin{tabular}{|l|l|l|l|l|l|}
\hline $\begin{array}{l}\text { PSEUDONYM } \\
\text { DRAWN FROM } \\
\text { FAMOUS } \\
\text { CHEMISTS* }\end{array}$ & $\begin{array}{l}\text { CO- } \\
\text { AUTHOR }\end{array}$ & $\begin{array}{l}\text { PROFESSIONAL } \\
\text { ROLE }\end{array}$ & $\begin{array}{l}\text { HSTEM } \\
\text { COURSE } \\
\text { ROLE(S) }\end{array}$ & $\begin{array}{l}\text { SEMESTER(S) } \\
\text { INVOLVED IN } \\
\text { HSTEM } \\
\text { COURSE }\end{array}$ & $\begin{array}{l}\text { IDENTITY } \\
\text { CATEGORIES }\end{array}$ \\
\hline Gerty & Yes & $\begin{array}{l}\text { Staff; Center } \\
\text { for Teaching } \\
\text { and Learning }\end{array}$ & $\begin{array}{l}\text { Consultant; } \\
\text { Assessment } \\
\text { Coordinator }\end{array}$ & $\begin{array}{l}\text { 2018 Spring, } \\
2018 \\
\text { Summer, } \\
\text { 2019 Spring, }\end{array}$ & $\begin{array}{l}\text { Female; } \\
\text { White }\end{array}$ \\
\hline
\end{tabular}

Bunnell, S.L., Lyster, M.M., Greenland, K.B., Mayer, G., Gardner, K., Leise, T., Kristensen,T., Ryan, E., 34 


\begin{tabular}{|c|c|c|c|c|c|}
\hline & & & & 2020 Spring & \\
\hline Kathleen & Yes & $\begin{array}{l}\text { Staff; } \\
\text { Community } \\
\text { Engagement }\end{array}$ & $\begin{array}{l}\text { Co- } \\
\text { facilitator }\end{array}$ & $\begin{array}{l}\text { All Semesters } \\
\text { following } \\
2016 \text { Spring }\end{array}$ & $\begin{array}{l}\text { Female; } \\
\text { White }\end{array}$ \\
\hline Rosalind & Yes & $\begin{array}{l}\text { Staff; Science } \\
\text { Librarian }\end{array}$ & $\begin{array}{l}\text { Co- } \\
\text { facilitator }\end{array}$ & $\begin{array}{l}2017 \text { Fall, } \\
2018 \text { Spring, } \\
2019 \text { Spring }\end{array}$ & $\begin{array}{l}\text { Female; } \\
\text { White; } \\
\text { LGBTQIA+ }\end{array}$ \\
\hline Marie & Yes & Student & Pioneer & 2016 Spring & $\begin{array}{l}\text { Female; } \\
\text { White; } \\
\text { LGBTQIA+ }\end{array}$ \\
\hline Ida & Yes & $\begin{array}{l}\text { Faculty; } \\
\text { Assistant } \\
\text { Professor }\end{array}$ & $\begin{array}{l}\text { Co- } \\
\text { facilitator }\end{array}$ & $\begin{array}{l}2018 \\
\text { Summer }\end{array}$ & $\begin{array}{l}\text { Female; } \\
\text { White }\end{array}$ \\
\hline Dorothy & Yes & $\begin{array}{l}\text { Faculty; Full } \\
\text { Professor }\end{array}$ & $\begin{array}{l}\text { Co- } \\
\text { facilitator }\end{array}$ & $\begin{array}{l}2018 \\
\text { Summer }\end{array}$ & $\begin{array}{l}\text { Female; } \\
\text { White }\end{array}$ \\
\hline Irene & Yes & $\begin{array}{l}\text { Staff; } \\
\text { Instructor }\end{array}$ & $\begin{array}{l}\text { Co- } \\
\text { facilitator }\end{array}$ & 2017 Fall & $\begin{array}{l}\text { Female; } \\
\text { White }\end{array}$ \\
\hline Gertrude & Yes & Student & Pioneer & 2016 Spring & $\begin{array}{l}\text { Female; } \\
\text { White }\end{array}$ \\
\hline Percy & Yes & $\begin{array}{l}\text { Staff; } \\
\text { Instructor }\end{array}$ & $\begin{array}{l}\text { HSTEM Lab } \\
\text { Study } \\
\text { Design and } \\
\text { Instruction }\end{array}$ & 2018 Fall & Male; Black \\
\hline Uma & Yes & $\begin{array}{l}\text { Faculty; } \\
\text { Associate } \\
\text { Professor }\end{array}$ & $\begin{array}{l}\text { Pioneer and } \\
\text { Co- } \\
\text { facilitator }\end{array}$ & All semesters & $\begin{array}{l}\text { Female; Bi- } \\
\text { Racial; } \\
\text { LGBTQIA+ }\end{array}$ \\
\hline Stephanie & No & $\begin{array}{l}\text { Student and } \\
\text { then Post- } \\
\text { baccalaureate } \\
\text { fellow }\end{array}$ & $\begin{array}{l}\text { Pioneer and } \\
\text { Co- } \\
\text { facilitator }\end{array}$ & $\begin{array}{l}2016 \text { Spring, } \\
2016 \text { Fall }\end{array}$ & $\begin{array}{l}\text { Female; } \\
\text { White; } \\
\text { LGBTQIA+ }\end{array}$ \\
\hline Alice & No & Student & Pioneer & 2016 Spring, & Female; Black \\
\hline
\end{tabular}

Bunnell, S.L., Lyster, M.M., Greenland, K.B., Mayer, G., Gardner, K., Leise, T., Kristensen,T., Ryan, E., 35 


\begin{tabular}{|l|l|l|l|l|l|}
\hline & & & & $\begin{array}{l}\text { 2017 Fall, } \\
\text { 2018 Spring }\end{array}$ & \\
\hline Paula & No & Student & Pioneer & 2016 Fall & Female; Black \\
\hline Yvonne & No & Student & Pioneer & 2016 Fall & $\begin{array}{l}\text { Female; } \\
\text { White }\end{array}$ \\
\hline Nancy & No & $\begin{array}{l}\text { Post- } \\
\text { baccalaureate } \\
\text { fellow }\end{array}$ & $\begin{array}{l}\text { Co- } \\
\text { facilitator }\end{array}$ & $\begin{array}{l}2017 \text { Fall, } \\
2018 \text { Spring }\end{array}$ & Female, Asian \\
\hline Hazel & No & $\begin{array}{l}\text { Post- } \\
\text { baccalaureate } \\
\text { fellow }\end{array}$ & $\begin{array}{l}\text { Co- } \\
\text { facilitator }\end{array}$ & $\begin{array}{l}\text { 2018 } \\
\text { Summer, } \\
2019 \text { Spring }\end{array}$ & White \\
\hline
\end{tabular}

*To learn more about some of these chemists, visit https://www.compoundchem.com/2017/03/07/female-chemists/, https://www.sciencehistory.org/learn/women-in-chemistry

\section{REFLECTING ON THE EXPERIENCE OF DEVELOPING AND FACILITATING HSTEM}

The original impetus for the HSTEM course was to effect change on campus, specifically through partnering with students to address barriers to belonging and thriving in STEM. The continued demand for this course at Amherst is itself a positive change, as is the development of HSTEM courses at eleven other institutions. There are also some critical outcomes of the HSTEM initiative that point to its additional impact. To better understand this impact, we asked all individuals (i.e., HSTEM students who pioneered the course in 2016, post-baccalaureate fellows, and faculty and staff HSTEM course co-facilitators) involved in the development and ongoing implementation of the Amherst HSTEM Initiative to write personal reflections about their experiences in HSTEM and the ways in which participation in this work has impacted their thinking about themselves, their experience as teachers and/or learners, and their investment in issues of diversity and inclusion. We present summaries of each of these sets of reflections below.

\section{Reflections from the HSTEM pioneers}

All students taking the ongoing HSTEM course investigate the topic of STEM inclusion with the purpose of bettering the Amherst STEM community and participating as partners in curricular decisions. However, identifying and shaping the group projects, designing the community events, and co-creating the original HSTEM course was a unique experience for the first nine HSTEM students, or pioneers. They were motivated to join this effort in order to 
continue "the momentum we gained during Amherst Uprising," in the words of Paula, a Black female pioneer. In reflecting on this experience, the pioneers reported that following this transformative moment for the college, the combination of studying the intersection of STEM, identity, and success, alongside interviewing their peers about their individual STEM pathways, shaped them across several dimensions.

On the academic side, the pioneers benefited from engaging with research and putting the experience of themselves and Amherst students into a broader context. Yvonne, a White female pioneer, wrote that the experience "opened [her] eyes to the breadth of challenges historically underrepresented groups face in STEM and provided [her] with new insights into [her] own experience." Together, the pioneers discovered that they felt less alone after learning about classroom challenges others were facing. Interviewing staff, alumni, and fellow students allowed the pioneers to place many of their negative individual academic experiences in a broader context. As Gertrude, a third HSTEM pioneer and co-author on this article, reflected, "I had moments when I genuinely believed I wasn't intelligent enough to pursue medicine, but the vulnerabilities that we were able to access through HSTEM helped me realize that my concerns were not atypical."

HSTEM pioneers also reported that taking ownership over a piece of Amherst's culture led to improved relationships with the school. In Gertrude's reflection, she also stated that participating in the course "was a way for [her] to feel like [she] had a real voice and say in the Amherst community." This sentiment was echoed by Stephanie, a White female pioneer who later served as a post-baccalaureate fellow for the HSTEM Initiative. She said that prior to her time in HSTEM, "[she] was frustrated and ready to be done with college, and [she] didn't really care about anyone else's experiences because it felt like in some ways no one had cared about [hers]." Following the course, Stephanie said,

My participation in the class helped to validate my frustrations and uncover just how common my experiences were among my peers. Instead of allowing me to wallow in that anger, though, the class provided a vehicle for and the empowerment to channel those emotions into what felt like real change. Over the semester, my mindset shifted from wanting to escape Amherst to a strong desire to improve the experiences of students coming after me.

The experience of co-creating the Being Human in STEM Initiative increased the pioneers' stakes in the Amherst community, providing a thread of continuing connection, belonging, and personal investment.

Many HSTEM pioneers also reported feeling encouraged by witnessing how dissatisfaction could be harnessed into action, as articulated by Yvonne: "My time in HSTEM taught me how powerful candid discussions about personal experiences can be and not to shy away from talking openly about uncomfortable topics." Marie, a White female LGBTQIA+ student noted, "Having a skillset around inequity (and dismantling it) has been a huge 
confidence-booster-it's allowed me to say 'Yes! Not only do I want to help, but I CAN help.'” For some, this caused a reimagination of the trajectory their post-undergraduate careers could follow-how might they take advantage of the tools available to them to tackle the challenges of their chosen field? Which "problems" might be reconceptualized as opportunities for improving the lives of others?

Finally, the pioneers learned how to partner with stakeholders to achieve shared outcomes. Alice, a Black female pioneer, reflected,

During the tense moments of Amherst Uprising, we argued at length about whether or not we should collaborate with the administration. Many were extremely hesitant about senior administrators and their intentions. Moving forward, I've adopted a mindset geared towards fruitful collaborations between diverse members of my communities in hopes of enacting change.

\section{Reflections from the post-baccalaureate HSTEM fellows}

As of this writing, three individuals have served as post-baccalaureate HSTEM fellows. These fellows indicated that they felt that their liminal positionality created an important connection between faculty/staff and current student experiences. Nancy, a female HSTEM fellow of Asian descent, said that she

served an important role as the bridge since part of the issue HSTEM is trying to address is the disconnect between students and faculty/staff. There is not only the difference in age but also in power dynamic and in perspective/priorities.

Similarly, a White female HSTEM post-baccalaureate fellow, Hazel, reported,

In many ways, I was learning alongside with the students. . . I I was able to share my experiences from an older, near-peer perspective, which I believe helped the students share their own. Viewing and sharing my experiences in that way was helpful for me as well; I felt very invested by my role as a mentor for these students.

The position of these post-baccalaureate fellows has facilitated students' listening to faculty and staff and staff and faculty listening for the contributions of student partners.

\section{Reflections from faculty and staff HSTEM course facilitators}

In addition to the benefits for students, it is clear that this work has shaped the faculty and staff HSTEM partners as well. When asked about the strengths of the HSTEM model, Percy, a Black male instructor involved in the HSTEM lab study, said that he views the HSTEM Initiative as "an engine of both social and scientific change." Similarly, Rosalind, a White female science 
librarian and co-facilitator of the HSTEM course, spoke about how HSTEM empowers students to enact change in their learning environment:

This course started as a response by students to an environment that invited them in but was not welcoming, and that has failed in many ways to support their growth. The strength of the course as I see it, is that students are able to respond to their negative experiences with collective action. ... The students are already activists when they start the course, but the formalized structure helps provide a conduit to faculty and administration so their voices are amplified.

Facilitating an HSTEM course offering has also informed faculty and staff members' pedagogical approaches more broadly. A White female tenure-track professor and HSTEM course co-facilitator, Ida, said that she is now "more open with students about [her] own experiences." She added:

As a consequence of HSTEM, I made a deliberate decision to share with students stories about my own failures and moments of doubt. I am a junior faculty member, and I am the only female faculty member in my department, in a field where women are underrepresented. Participating in the HSTEM initiative has increased my awareness not only of the importance of inclusivity in my classroom, but also of the importance of building a community for myself.

Another course co-facilitator, Dorothy, who is a White female full professor, said,

After the HSTEM discussions I can see ways ahead starting with small steps in my courses, advising, and undergrad research. It's only a small part of what is needed, and there is institutional-level change that has to happen, but it feels good to be able to do some things that could help a student feel more confident about their path.

Finally, Rosalind also wrote that her experience partnering with students through HSTEM "has affected all of the other work [she does], and has made it even clearer to [her] that inclusive and transparent teaching practices are essential."

Importantly, several individuals spoke about being prompted to reflect on their own positionality and desires to be involved in diversity and inclusion efforts. For example, Kathleen, a White female staff member at the college who has contributed to seven of the eight HSTEM course offerings, reflected,

In the wake of the Amherst Uprising, I desperately wanted to do something that would provide meaningful support for the members of our community who shared experiences of marginalization. ... I had many moments of uncomfortable self- 
reflection during which I had to grapple with my own privilege and positionality in ways I hadn't before. The impact of those experiences extends far beyond HSTEM and has helped me to become a more reflective and curious human.

Uma, a biracial LGBTQIA+ female associate professor, also reflected on her own identities and desire to act on behalf of students, saying,

As a lesbian woman of color in STEM, their feelings of alienation, invisibility, and doubt about belonging resonated with me. Designing a class with the students to apply a scientific and human lens to the experience of being human in STEM felt like a concrete and meaningful action I could take to honor the courage of the students who spoke out.

TWO INQUIRY PROJECTS: EVALUATING THE IMPACT OF THE HSTEM INITIATIVE ON STUDENTS' PERSISTENCE AND SENSE OF BELONGING IN STEM

In addition to the personal reflections of HSTEM student pioneers, post-baccalaureate fellows, staff, and faculty, we are also interested in whether two signature components of the HSTEM Initiative contributed to students' sense of belonging in STEM as well as their likelihood of continuing in STEM disciplines over time. Therefore, in the next section we present the results of two inquiry projects exploring these questions. The first project was conducted in introductory science labs whose course design either did or did not intentionally emphasize a subset of pedagogical practices from the HSTEM Inclusive Curricular Practices Handbook. The second project examines student reflections following the completion of a condensed HSTEM course that integrated the four core phases of the HSTEM model. Specifically, we were interested in the following questions:

1) How does students' sense of belonging and persistence in STEM relate to their experiences of intentional inclusive teaching in an introductory STEM lab course?, and

2) How does students' thinking about themselves and their identities shift as a result of taking the HSTEM course?

\section{Sense of belonging and persistence in STEM: Links to HSTEM curricular practices in an introductory science lab}

In a large, introductory science course at our institution, students were enrolled in one of two lecture sections based on their level of high school mathematics preparation and one of seven randomly selected laboratory sections. In order to evaluate the impact of HSTEM curricular practices on students' sense of belonging in STEM, their likelihood of continuing in STEM, and their awareness of how their identities influenced their learning in STEM, two of the laboratory sections were taught using pedagogical practices aimed at building community and supporting collaboration outlined in the HSTEM curricular handbook. The other five laboratory 
sections were taught using a traditional instructional format. To control for instructor-level influences, the two instructors who taught the lab sections that integrated handbook-specific HSTEM practices also each taught a traditional laboratory section. All lab sections conducted the same laboratory experiments throughout the semester, and students completed surveys about their experiences, sense of belonging, and their likelihood of persisting in STEM at the beginning and end of the semester.

\section{Traditional (non-HSTEM) lab methods}

The non-HSTEM lab structures focused on developing scientific skills and accomplishing the lab tasks without an additional emphasis on community building or belonging. At the beginning of each lab, students were provided with a pre-lab lecture which provided instructions for how to successfully complete that day's experiments. Students selected their lab partners on their own, typically based on existing friendships or connections with other students in the lab (e.g., athletic teammates, roommates), and they remained in that partnership throughout the semester.

\section{HSTEM lab methods}

In addition to the development of scientific skill-building taught in the traditional lab sections, the HSTEM lab sections also drew on practices highlighted in the HSTEM Inclusive Curricular Practices Handbook that target the building of community and collaboration. During the first lab meeting of the semester, the instructor welcomed each student as they arrived to class with a handshake, an introduction of themself, and solicitation of the student's preferred name. Next, the instructor, teaching assistant, and students participated in an icebreaker activity using paper airplanes, in which each person wrote their name and three "getting to know you" questions on a blank piece of paper. Participants then flew airplanes around the room for two minutes. Participants then selected a random airplane to return to its original owner and engaged that individual in one-on-one discussion about the questions. Finally, students introduced one another to the larger class. After this good-natured "chaos" and movement, the instructor emphasized that the class was to be an inclusive learning community and articulated the importance of valuing and respecting all students. Lastly, the lab instructor introduced the idea of "community announcements time" at the beginning of lab each week, during which time everyone was encouraged to share news about events and activities that they were involved in outside of STEM.

Throughout the semester, community announcements were augmented by two additional inclusion efforts. First, students were randomly paired with a different partner for each lab. Each week, students were given the front or back of a trading card; these cards pair images of URM scientists with corresponding background information. At the end of the pre-lab lecture, students identified their partner by matching their cards. Secondly, in their weekly lab reports, students responded to three reflective writing prompts about partnership: (a) What behaviors from yourself or your partner(s) enhanced your experience with this particular lab 
and/or your understanding of the material?, (b) What did you do well in your group this week?, and (c) What did your partner do well in your group this week?

\section{HSTEM lab study participants}

Ninety-three students completed the pre-test survey and 89 students completed the post-test survey. The number of students who completed the pre-test and post-test surveys, according to high school math preparation level and HSTEM or traditional lab participation, is included in Table 2. Response rates of students in the non-HSTEM lab sections were lower than response rates by students in the HSTEM lab sections.

Table 2. Frequency counts of students completing pre-test and post-test surveys according to lecture course placement and lab type, with response rates in parentheses

\begin{tabular}{|l|l|l|l|l|}
\hline GROUP & $\begin{array}{l}\text { HIGH SCHOOL } \\
\text { MATH } \\
\text { PREPARATION } \\
\text { LEVEL }\end{array}$ & LAB TYPE & $\begin{array}{l}\text { NUMBER OF } \\
\text { STUDENTS WHO } \\
\text { COMPLETED } \\
\text { PRE-TEST } \\
\text { SURVEY }\end{array}$ & $\begin{array}{l}\text { NUMBER OF } \\
\text { STUDENTS WHO } \\
\text { COMPLETED } \\
\text { POST-TEST } \\
\text { SURVEY }\end{array}$ \\
\hline 1 & Less Preparation & Non-HSTEM & $34(63 \%)$ & $34(63 \%)$ \\
\hline 2 & Less Preparation & HSTEM & $18(82 \%)$ & $15(68 \%)$ \\
\hline 3 & $\begin{array}{l}\text { More } \\
\text { Preparation }\end{array}$ & Non-HSTEM & $24(62 \%)$ & $18(46 \%)$ \\
\hline 4 & $\begin{array}{l}\text { More } \\
\text { Preparation }\end{array}$ & HSTEM & $16(84 \%)$ & $18(95 \%)$ \\
\hline
\end{tabular}

Relationship between HSTEM or non-HSTEM lab section and STEM persistence

In terms of likelihood of taking another STEM class at the end of the semester, there were no significant differences between students in the HSTEM and non-HSTEM lab sections when controlling for pre-test likelihood of taking another STEM course. While the regression model predicting students' perceived likelihood of taking another STEM class at the end of the semester, based on group (as specified in Table 2) and pre-test perceived likelihood of taking another STEM course, was significant $(F(4,67)=21.49, p<.001)$, the effect was driven by students' pre-test responses. It is important to note that these scores were not normally distributed, as the vast majority of students rated themselves as a 4 or a 5 (out of 5) as likely to take another STEM class ( $98 \%$ at pre-test and $95.5 \%$ at post-test). This pattern is not surprising, given that this introductory science course is the entry course for most students interested in pursuing a career in science and/or medicine. 
When we look at changes in group trends in providing a rating of highest likelihood of taking another STEM class at the end of the semester, however, we do see some trends suggesting that HSTEM lab participation had a positive impact. Specifically, in non-HSTEM lab sections, we see no change in the percentage of students most likely to take another STEM class (in students with less high school math preparation) and a substantial decrease of almost $10 \%$ in the percentage of students most likely to take another STEM class (in students with more high school math preparation); these patterns stand in direct contrast to the increase in the percentage of students who indicated the highest likelihood levels of taking another STEM class in both sections of the HSTEM lab (see Figure 3).

Figure 3. Percent change in students endorsing a highest likelihood rating (5 out of 5) of taking another STEM course at post-test, according to lab section and high school preparation level

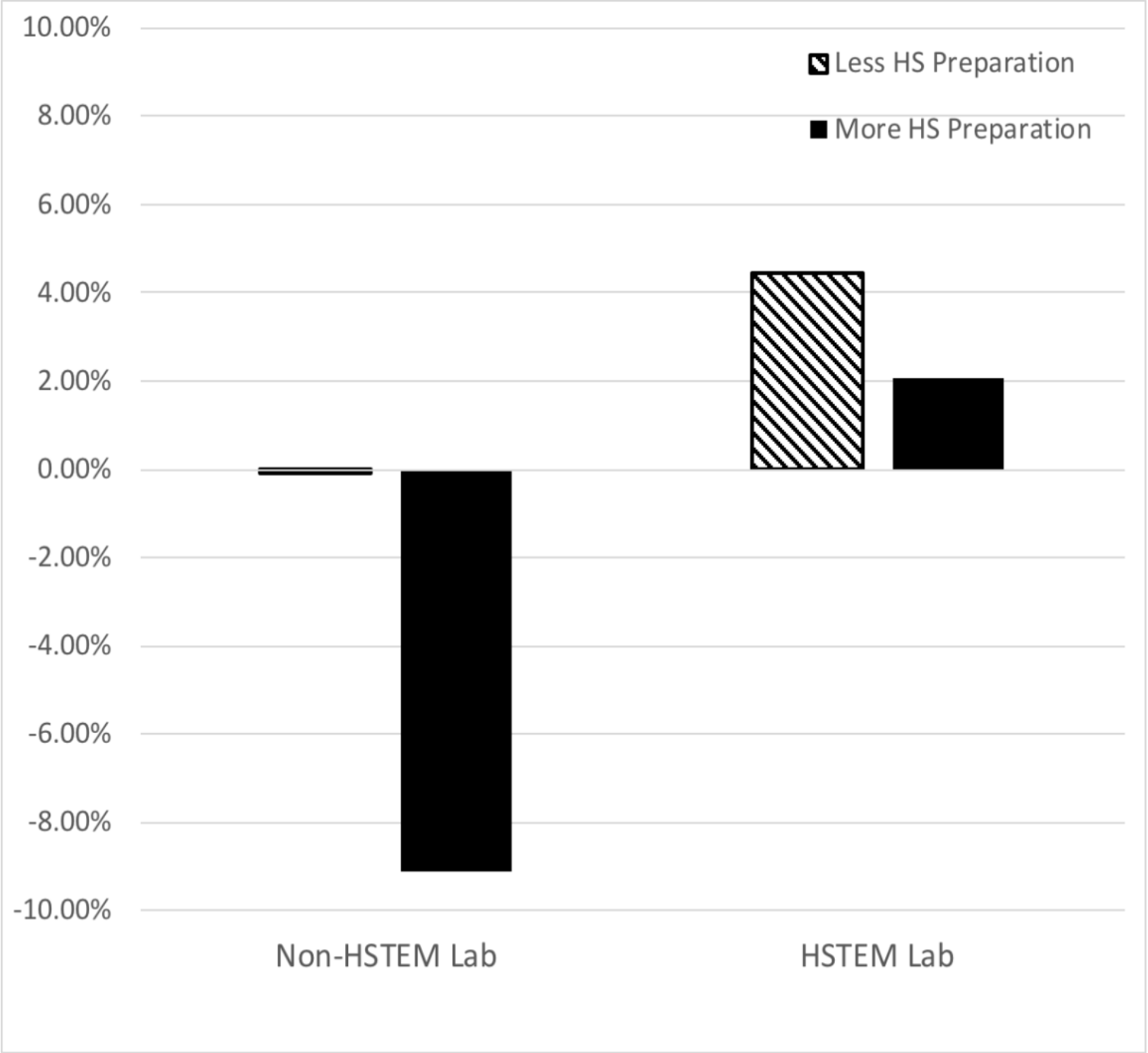




\section{Relationship between HSTEM or non-HSTEM lab section and sense of belonging}

In Table 3, we summarize the themes that emerged from all students' responses to the post-test survey question: "How do your individual identities (gender, class, race, sexuality, geographic upbringing, other) influence your learning in STEM classes?" This thematic analysis was conducted using an inductive thematic analysis approach (e.g., Braun \& Clarke, 2006), such that each response was first read to identify all categories of identity presented in the text. Many responses discussed more than one aspect of identity that the individual felt contributed to their experience in STEM courses. At that point, a secondary analysis was conducted at the sentence level to evaluate whether the author presented a particular aspect of their identity as either positively or negatively contributing to their STEM experience. All responses were independently coded by two coders, with inter-rater reliability at $100 \%$.

Table 3. Thematic analysis of students' reported impact of identity on experience in STEM according to high school (HS) preparation level and non-HSTEM or HSTEM lab section

\begin{tabular}{|c|c|c|c|c|c|}
\hline \multirow[b]{2}{*}{ THEME } & \multirow[b]{2}{*}{$\begin{array}{l}\text { IMPACT } \\
\text { TYPE }\end{array}$} & \multicolumn{2}{|c|}{ NON-HSTEM LAB SECTIONS } & \multicolumn{2}{|c|}{ HSTEM LAB SECTIONS } \\
\hline & & $\begin{array}{l}\text { Less HS } \\
\text { preparation }\end{array}$ & $\begin{array}{l}\text { More HS } \\
\text { preparation }\end{array}$ & $\begin{array}{l}\text { Less HS } \\
\text { preparation }\end{array}$ & $\begin{array}{l}\text { More HS } \\
\text { preparation }\end{array}$ \\
\hline \multirow[t]{2}{*}{ Female } & Positive & --- & --- & $8 \%$ & --- \\
\hline & Negative & $23 \%$ & $24 \%$ & --- & $12 \%$ \\
\hline \multirow[t]{2}{*}{ Male } & Positive & --- & $6 \%$ & --- & $6 \%$ \\
\hline & Negative & --- & --- & --- & --- \\
\hline \multirow{2}{*}{$\begin{array}{l}\text { Black or African- } \\
\text { American }\end{array}$} & Positive & --- & --- & --- & --- \\
\hline & Negative & $3 \%$ & --- & --- & --- \\
\hline \multirow{2}{*}{$\begin{array}{l}\text { Asian or Asian- } \\
\text { American }\end{array}$} & Positive & --- & --- & $8 \%$ & $6 \%$ \\
\hline & Negative & --- & $12 \%$ & $8 \%$ & $6 \%$ \\
\hline First Generation & Positive & --- & --- & --- & --- \\
\hline
\end{tabular}




\begin{tabular}{|l|l|l|l|l|l|}
\hline or Low Income & Negative & $6 \%$ & $6 \%$ & $8 \%$ & $6 \%$ \\
\hline $\begin{array}{l}\text { High School } \\
\text { Preparation }\end{array}$ & Positive & $3 \%$ & $12 \%$ & --- & $6 \%$ \\
\cline { 2 - 7 } & Negative & $7 \%$ & $6 \%$ & --- & $6 \%$ \\
\hline $\begin{array}{l}\text { Minority Status } \\
\text { (general) }\end{array}$ & Positive & $3 \%$ & --- & $23 \%$ & --- \\
\cline { 2 - 7 } & Negative & $7 \%$ & --- & $15 \%$ & --- \\
\hline
\end{tabular}

Nearly one quarter of the students in non-HSTEM lab sections across high school preparation levels indicated that being female was the largest, negative identity factor impacting their experience in STEM classes. For example, one student wrote:

I feel like I have to prove myself-show I am a good student and can do well in the class - to be taken seriously as a woman. I feel as if my questions are sometimes answered in a way that would assume I have less knowledge than my male peers.

Another individual said, "Sometimes I feel overwhelmed because I am a minority and I feel like I have to make sure I show that I am smart to represent my racial group in a positive way. This can make learning stressful."

In contrast, in the HSTEM lab sections, these students most commonly reported that holding a minority status in class positively contributed to their learning in STEM. For instance, one student wrote, "The more diverse we are, the more inclusive and comfortable it is," while another student said, "I believe my ethnic group enhances my learning because it introduces a special dynamic in the lab." Finally, a third student reported, "I feel proud to be a woman in STEM and love to see how many other girls are doing so well in my lab section."

\section{Student reflections on their experiences and learning in an HSTEM course}

While the standard HSTEM seminar course is taught across the length of a semester (13 weeks), we offered a modified HSTEM course during an intensive, two-week Summer 2018 session. The specific curriculum for this course was co-designed with students in the Spring 2018 HSTEM class (see http://www.beinghumaninstem.com/summer-2018-condensedcourse.html). We were interested in how participation in this course may have shaped students' sense of belonging and inclusion in STEM. 


\section{HSTEM course methods}

Thirteen students ( $85 \%$ female-identifying) enrolled in this condensed version of the course. Immediately prior to the HSTEM course, all students participated in an eight-week summer research experience. As such, the research and project focus of the two-week HSTEM course was specifically about the intersection of "being human" with undergraduate STEM research experiences. The course began with a day of introductions and intensive community building, during which students first participated in the same airplane game icebreaker activity used in the HSTEM lab sections, followed by the co-establishment of community guidelines. Faculty members, including course facilitators and invited guests, shared their HSTEM stories, and then students wrote their own HSTEM stories. Students also were introduced to the HSTEM initiative by watching a short documentary by a previous HSTEM student (McNamara, 2018; http://www.beinghumaninstem.com/documentary.html). Throughout the course, students read research on diversity and inclusion in STEM and completed daily written reflections that served as the basis of class discussions.

Students also completed a group-based project focused on the student STEM research experience at Amherst. Groups were formed based on student preferences among the three project topics: (a) identifying pathways to STEM research, (b) analyzing survey data from former undergraduate STEM research fellows at Amherst, and (c) conducting and analyzing interviews with former Amherst STEM research fellows. In terms of the interview project, alumni from 2008-2016 who had participated in summer research during their time at the college were contacted by course co-facilitators to assess their interest in participating in an interview with an HSTEM student. Those who expressed interest were then contacted by the students for interviews, which were conducted via phone or video conferencing. These interviews were transcribed and read for common themes related to how participating in research fostered a sense of self, a connection to STEM and/or the college, and future career aspirations. At the end of the course, students presented their work at a community end-of-course poster session and responded to the following writing prompt: "Please reflect on the past two weeks: What you learned and felt in response to the readings, discussions, in your project groups, and any other aspects of the workshop."

\section{Evidence of course impact}

We examined students' end-of-course reflections on how their thinking about themselves and their positionality in STEM had changed across the previous two weeks. Student responses were classified based on the following themes: (a) aspects of self that positively impacted their experience in STEM, (b) aspects of self that negatively impacted their experience in STEM, and (c) impact of the HSTEM course experience on one's self knowledge and affect. The two-step approach of inductive thematic content analysis, which we describe earlier in this paper, was employed to evaluate this set of student responses as well. 
Positive aspects of self and STEM identity

Many students wrote about the positive role of family in encouraging their motivation to pursue STEM. One student said, "My mother encouraged me to not give up on math in particular, because she herself had essentially convinced herself not to pursue STEM careers even though engineering would likely have been a great fit [for her]." Similarly, another student mentioned the positive influence of maternal encouragement: "My mom, being a geology major in college, always told me, 'You just haven't found the right science for you yet.'”

Negative aspects of self and STEM identity

Conversely, participants described three factors negatively impacting their experiences in STEM: a sense that STEM was the only mechanism by which they could improve their socioeconomic status, a belief that initial struggle in STEM indicated that they could not be successful, and a lack of belonging in STEM due to their identities being underrepresented in STEM. For instance, one individual described how struggling with coursework discouraged her pursuit of STEM:

Math was always something that I knew I could do. . . I I think something that dissuaded me from dedicating myself to math was how I had done poorly on an exam in my high school geometry class and it had shattered my pride in being "naturally" good at math. . .. I was never able to regain the confidence that I'd had before.

Another student's comments reflected the challenge of underrepresentation:

The first semester of my first year [in college], I took chemistry. . . I I was embarrassed about how far behind I was compared to everyone else, and I didn't feel comfortable expressing this to anyone that first semester because I felt that my presence in STEM classrooms as a woman was somewhat of a statement. Now I was here in a science class in a really good school, and I felt I had something to prove, and like I had to earn my keep.

Reflections on the HSTEM course experience

When asked how their thinking had changed after participating in the HSTEM course, participants responded that the primary outcome was an increased understanding of the challenges facing minority students in STEM disciplines, coupled with motivation to enact change. One student said HSTEM "pushed [the student] to look at what can be fixed, the specific issues and their specific causes, but also how to create solutions to those problems that can be implemented practically." Finally, when asked about the affective experience of the HSTEM course, students' responses were divided. Many students indicated the psychological challenge of engaging with stories of struggle and exclusion, while many of those same students also reflected on the affirming and empowering experience of the course. And, students 
reflected on the relief they experienced upon the realization that their instructors also struggled to feel included in STEM. One such comment was: "I especially liked hearing professors' HSTEM stories and learning about some of the challenges they experienced in their academic careers. It was encouraging to learn that even successful professors doubted that they had enough academic brilliance to succeed."

\section{DISCUSSION}

Being Human in STEM demonstrates the potential to activate protest into change through meaningful partnership with students. The HSTEM initiative is working to legitimize inclusion and diversity efforts as a worthy endeavor in STEM by amplifying student voices and experiences, and we see positive impacts in student learning and reflections, as well as powerful personal changes in the reflections of student, faculty, and staff partners as a result. The HSTEM course pairs academic inquiry with community engagement and action. Students read literature on diversity, equity, and inclusion to ground their investigations. Using a facilitated community-based project design approach, students apply what they have learned to propose interventions to enhance the experience of others in the STEM community. By building the HSTEM initiative around an academic course, we have been able to institutionalize ongoing attention to the conversation around diversity and inclusion. The course structure also allows for experimentation with and development of inclusive pedagogical resources. Further, its emphasis on engaging with the academic literature and data collection applies the scientific process to the work of inclusion: we ask questions, make observations, analyze and interpret data, and continue to refine our process.

This approach differs from other institutional models in that it partners with students to shape and direct institutional change in STEM, rather than offering supplementary, institutionally authored support to students, so that they can overcome potential barriers to their educational success. While we believe that those supports, such as metacognitive instruction, cohort building, and courses on the inequities that exist in STEM, are critical aspects of helping all students thrive in higher education, we argue that students are much better positioned to inform these efforts and, through partnership, can help us see the ways in which institutional structures, often built to support only a subset of our students, can be modified or reimagined to support all of our students. As described by Bloch-Shulman and Castor (2015), "academic institutions gravitate towards [processes that are] effectively barring students from significant decision-making processes pertaining to their own education" (p. 169). To counteract these processes, the authors argue that in order "to not dominate, to not limit students' self-determination, it is necessary that they collaborate in task-defining and to not assume, as faculty members, that we know completely what is best for them" (p. 170). We see the Students-as-Partners approach of the Being Human in STEM Initiative as an intentional effort to allow students to define and work towards a more inclusive STEM community.

It should be noted that in 2014, students at Brown University utilized a special topics format (a group independent study project, or GISP) to create a course entitled "Race \& Gender 
in the Scientific Community" (http://racegenderscience.weebly.com/), which incorporated an expansive reading list from the academic literature on race, gender, and other identities in STEM. This special topics course was also student-designed, and it has become institutionalized such that it is now an established course in the university curriculum (Silber, 2018). Being Human in STEM emerged independently and without knowledge of these efforts at Brown; since discovering our shared work, the "Race and Gender in the Scientific Community" course has become allied with the Being Human in STEM Initiative and our growing HSTEM network.

Although HSTEM has led to positive impacts on student learning and increased faculty and staff investment in diversity and inclusion efforts and has been adopted by many institutions across the United States, there are ongoing challenges to sustaining and expanding this work. A key question that emerged for us, as the urgency of the Amherst Uprising dissipated and student leaders graduated, was how to maintain energy for centering inclusion in our educational mission. Until over-advantaging of majority students throughout the precollege educational preparation ceases, inequities at the collegiate level will continue to harm students, no matter the level of institutional diversity. We believe that highlighting personal narratives will continue to be a powerful strategy and way forward, one which emphasizes the vast work around diversity, equity, and inclusion that remains on our own campuses, not to mention the broader higher educational context. We hope that the unprecedented response in the international STEM community to the police killings of George Floyd, Breonna Taylor, Ahmaud Arbery, and others, such as the observation of \#ShutDownSTEM (https://www.shutdownstem.com/) on June 10, 2020 to engage in anti-racism education, organizing, and action, signals the beginning of an authentic and sustained awareness of the urgency of inclusivity in STEM.

In addition to maintaining the energy for inclusive STEM education, sustainability is also an ongoing concern in terms of capacity building - how can we bring new voices and partners into HSTEM to both share the labor and to think in new ways about student partnership around inclusion? And, how can we maintain an approach to HSTEM that equitably partners with students around course design, assessment, and goals for the initiative? As HSTEM has developed a more formalized structure through its eight iterations, how do we continue to allow for it to be driven and changed by students? While we have not solved this challenge, we have realized the importance of being transparent with students about where they can more readily shape classroom and institutional structures. Finally, we see clear transferability of the HSTEM model to disciplines beyond STEM which also struggle with inclusive curriculum and student belonging, and we continue to look for partnerships in the humanities and arts to sustain and expand this work. One step in this direction is through diversifying the disciplinary backgrounds of HSTEM course instructors; indeed, one of the course co-facilitators of the Spring 2020 HSTEM course was a sociologist.

Being Human in STEM grew out of a critical moment in Amherst College history. While student protests are an enduring feature on many college campuses, the courage and vulnerability of students who exposed the pain of their lived experiences during Amherst 
Uprising, coupled with the response by faculty, staff, and administration to listen and partner with students, has led to a unique outcome for our campus community. As reflected in the HSTEM process model (Figure 4), STEM faculty and staff listened to what the students shared, then departments and programs validated student concerns by writing letters of support. After reflecting on their own journeys and experiences, faculty and staff members chose to partner with students in developing a pathway forward. This process continues to serve as the basis for HSTEM collaboration - among co-facilitators and students during the course, students and campus partners during project design, veteran and novice HSTEM course facilitators during course planning, and building community within the expanding HSTEM institutional network. Together, the HSTEM course model (see Figure 2) and HSTEM process model (see Figure 4) offer a promising foundation for creating community change that is student-centered, evidence-based, and iteratively responsive to local needs.

Figure 4. HSTEM process model

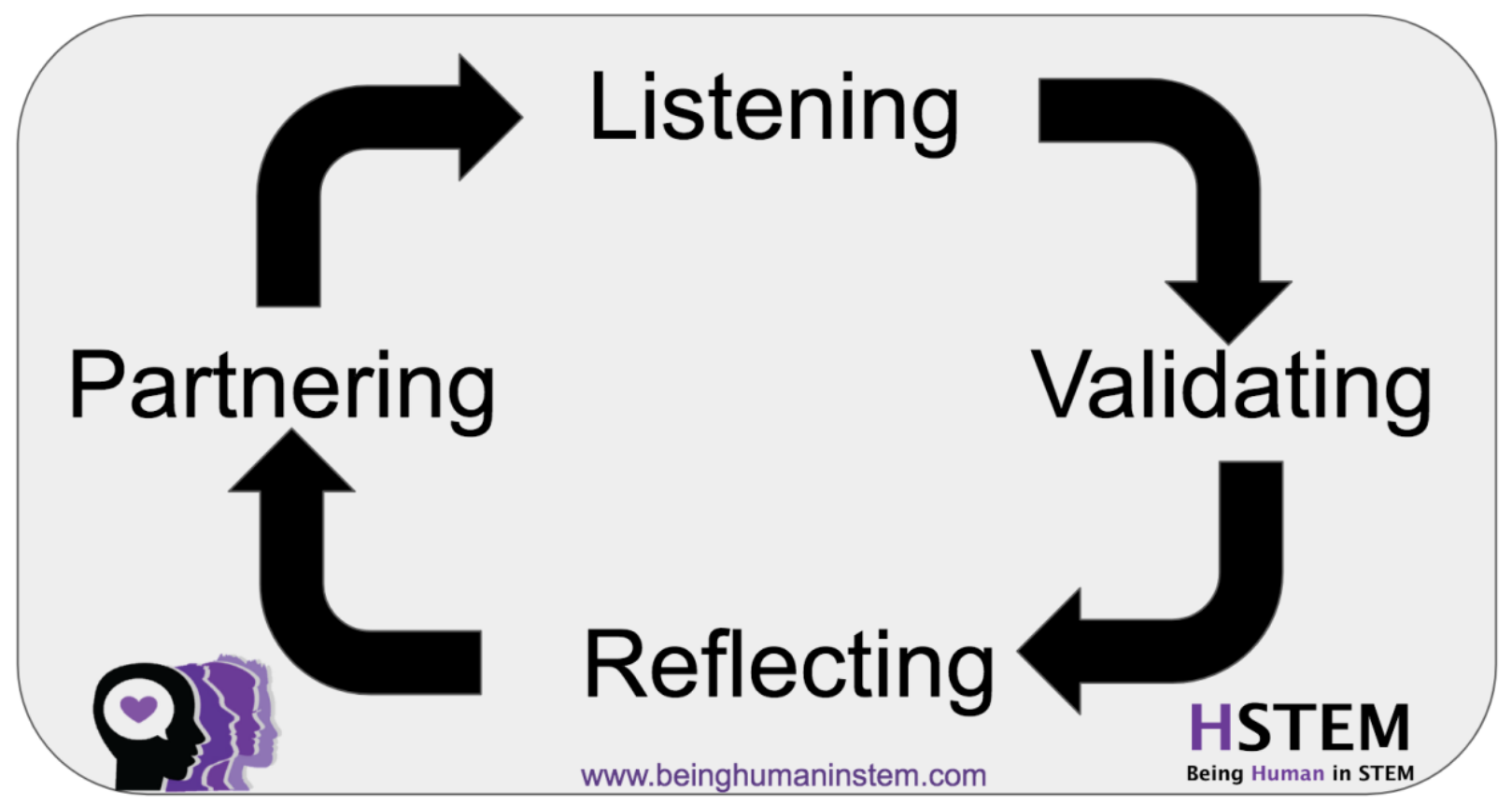




\section{ACKNOWLEDGEMENTS}

We would like to thank the many contributions that have made this work possible. First, the HSTEM pioneers (Doyin Ariyibi, Louise Atadja, Ashley Bohan, Ruth Manzanares, Chelsea Nkansah-Siriboe, Sanyu Takirambudde, Olivia Truax, and pioneer co-authors Ryan and Mayer) and HSTEM post-baccalaureate fellows. Specific thanks go to Michaela Ednie for her contributions to Figure 1. We also appreciate the many intellectual contributions of Amherst staff partners, including Dr. Caldwell-O'Keefe at the Center for Teaching and Learning, Dawn Cadogan of the Amherst College Library, and Jess Martin, Science Center Director. Financial support for HSTEM was provided by the following Amherst College offices and departments: Center for Community Engagement, Center for Humanistic Inquiry, Center for Teaching and Learning, Dean of Faculty Office, Department of Chemistry, Office of Diversity and Inclusion, and the Science Center.

\section{NOTE ON CONTRIBUTORS}

Sarah Bunnell is the Associate Director and STEM Specialist for the Center for Teaching and Learning at Amherst College. Her research currently focuses on how best to support students, faculty, and staff in building inclusive, impactful learning communities through meaningmaking, metacognition, and empathy.

Megan Lyster currently serves as the Assistant Director of the Wurtele Center for Leadership at Smith College. She previously held the position of Instructional Designer for Experiential Learning in the Amherst College Center for Community Engagement, where she supported and facilitated community-based and project-based learning initiatives inside and outside the classroom.

Kristen Greenland is currently the Chemical \& Physical Sciences Librarian at UC Berkeley and was the Science Librarian at Amherst College during the formative years of the HSTEM initiative. Her work is focused on providing research and instructional support in the sciences by partnering with faculty, staff, and students.

Gabrielle Mayer graduated from Amherst College, where she helped found the HSTEM course. She is an internal medicine resident at NYU. Her research interests include health disparities and social determinants of health with emphasis on LGBTQ+ care and housing instability.

Kristen Gardner is an Assistant Professor of Computer Science at Amherst College. Her research focuses on developing probabilistic analyses of computer systems. In the classroom, she is particularly interested in fostering an inclusive environment to encourage retention of underrepresented students in computer science. 
Tanya Leise is a Professor of Mathematics at Amherst College. As an applied mathematician, she engages her students in course projects and undergraduate research in agent-based modeling, time-frequency analysis of biological oscillations, and the mathematics of voting.

Thea Kristensen is a Biology Department Laboratory Coordinator at Amherst College. She infuses inclusive teaching practices into designing and teaching lab courses. In addition to research in modeling population size and distribution of wildlife species, Thea actively seeks out opportunities to research how to augment the student experience in STEM courses.

Emma Ryan graduated from Amherst College, where she helped found and grow the HSTEM course over three semesters. She is currently in her third year at the University of Washington School of Medicine.

Richmond Ampiah-Bonney is an Academic Manager of the Chemistry Department at Amherst College. He uses a variety of pedagogical methods and one-on-one, group and class-based instruction to support student progress in introductory chemistry courses.

Sheila Jaswal is an Associate Professor of Chemistry and Director of the HSTEM Initiative. With a team of undergraduate researchers, she studies protein folding using biophysical and computational approaches. As HSTEM Director, she facilitates the HSTEM course in collaboration with students, staff, and faculty and oversees the ever-expanding HSTEM network.

\section{REFERENCES}

Acai, A., Akesson, B., Allen, M., Chen, V., Mathany, C., McCollum, B., Spencer, J., \& Verwoord, R. E. M. (2017). Conceptualizations of success in student-faculty/staff SoTL partnerships: Motivations, challenges, power, and definitions. The Canadian Journal for the Scholarship of Teaching and Learning, 8(2). https://doi.org/10.5206/cjsotlrcacea.2017.2.8

Ahmed, S. (2012). On being included: Racism and diversity in institutional life. Duke University Press Books.

Ainsworth, M. D. (1989). Attachments beyond infancy. American Psychologist, 44, 709-716. https://psycnet.apa.org/doi/10.1037/0003-066X.44.4.709

Appel, M., Kronberger, N. \& Aronson, J. (2011). Stereotype threat impairs ability building: Effects on test preparation among women in science and technology. European Journal of Social Psychology, 41(7), 904-913. https://doi.org/10.1002/ejsp.835

Aronson, J., Quinn, D. M., \& Spencer, S. J. (1998). Stereotype threat and the academic underperformance of minorities and women. In J. K. Swim \& C. Stangor (Eds.), Prejudice: The target's perspective (p. 83-103). Academic Press. 
Baumeister, R. F. \& Leary, M. R. (1995). The need to belong: Desire for interpersonal attachments as a fundamental human motivation. Psychological Bulletin, 117, 497-529. https://psycnet.apa.org/doi/10.1037/0033-2909.117.3.497

Beasley, M. A., \& Fischer, M. J. (2012). Why they leave: The impact of stereotype threat on the attrition of women and minorities from science, math, and engineering majors. Social Psychology of Education, 15(4), 427-448. https://doi.org/10.1007/s11218-012-9185-3

Bloch-Shulman, S. \& Castor, M. (2015). I am not trying to be defiant, I am trying to be your partner: How to help students navigate educational institutions that do not value democratic practice. Partnerships: A Journal of Service Learning and Civic Engagement, 6(1).

Bohan, A., Ryan, E., Lyster, M., \& Jaswal, S. S. (2017, March 3-5). The being human in STEM initiative. [Workshop]. Understanding Interventions that Broaden Participation in Science Careers Conference, San Antonio, Texas.

Bovill, C. (2017). A framework to explore roles within student-staff partnerships in higher education: Which students are partners, when, and in what ways? International Journal for Students as Partners, 1(1). https://doi.org/10.15173/ijsap.v1i1.3062

Bovill, C., Cook-Sather, A., \& Felten, P. (2011). Students as co-creators of teaching approaches, course design, and curricula: Implications for academic developers. International Journal for Academic Development, 16(2), 133-145.

https://doi.org/10.1080/1360144X.2011.568690

Bovill, C., Cook-Sather, A., Felten, P., Millard, L. \& Moore-Cherry, N. (2016). Addressing potential challenges in co-creating learning and teaching: Overcoming resistance, navigating institutional norms and ensuring inclusivity in student-staff partnerships. Higher Education, 71, 195-208. https://doi.org/10.1007/s10734-015-9896-4

Braun, V., \& Clarke, V. (2006). Using thematic analysis in psychology. Qualitative Research in Psychology, 3(2), 77-101.

Bridges B. K., Cambridge, B., Kuh, G. D., \& Leegwater, L. H. (2005). Student engagement at minority-serving institutions: Emerging lessons from the BEAMS project. New Directions for Institutional Research, 125, 25-43. https://doi.org/10.1002/ir.137

Bunnell, S. L., Lin, B., Ednie, M., Lyster, M., \& Jaswal, S. S. (2019, March 28-30). Being human in STEM: How to build community and increase student success in the science and beyond [Conference poster session]. Association of American Colleges and Universities Diversity, Equity, and Student Success Conference, Pittsburgh, Pennsylvania.

Chickering, A. W., \& Gamson, Z. F. (1987). Seven principles for good practice in undergraduate education. AAHE Bulletin, 39(7), 3-7.

Cook-Sather, A. (2015). Dialogue across differences of position, perspective, and identity: Reflective practice in/on student-faculty pedagogical partnership programs. Teachers College Record, 117(2).

Cook-Sather, A. (2018). Listening to equity-seeking perspectives: How students' experiences of 
pedagogical partnership can inform wider discussion of student success. Higher Education Research \& Development, 37(5), 923-936. https://doi.org/10.1080/07294360.2018.1457629

Cook-Sather, A. \& Abbot, S. (2016). Translating partnerships: How faculty-student collaboration in explorations of teaching and learning can transform perceptions, terms, and selves. Teaching and Learning Inquiry, 4(2). https://doi.org/10.20343/teachlearninqu.4.2.5

De Bie, A., Marquis, E., Cook-Sather, A., \& Luqueño, L. P. (2019). Valuing knowledge(s) and cultivating confidence: Contributions of student-faculty pedagogical partnerships to epistemic justice. In J. Hoffman, P. Blessinger, \& M. Makhanya (Eds.), Strategies for fostering inclusive classrooms in higher education: International perspectives on equity and inclusion, 16. https://doi.org/10.1108/S2055-364120190000016004

Dewsbury, B., \& Brame, C. J. (2019). Inclusive teaching. CBE: Life Sciences Education, 18(2). https://doi.org/10.1187/cbe.19-01-0021

Espinosa, L. L. (2011). Pipelines and pathways: Women of color in undergraduate STEM majors and the college experiences that contribute to persistence. Harvard Educational Review, 81(2), 209-241. https://doi.org/10.17763/haer.81.2.92315ww157656k3u

Espinosa, L. L., Turk, J. M., Taylor, M., \& Chessman, H. M. (2019). Race and ethnicity in higher education: A status report. American Council on Education.

Estrada, M., Burnett, M., Campbell, A. G., Campbell, P. B., Denetclaw, W. F., Gutierrez, C. G., Hurtado, John, G. H., Matsui, J., McGee, R., Moses Okpodu, C., Robinson, T. J., Summers, M. F., Werner-Washburne, M., \& Zavala, M. (2016). Improving underrepresented minority student persistence in STEM. CBE Life Science Education, 15(3), 1-10. https://doi.org/10.1187/cbe.16-01-0038

Gurin, P., Dey, E. L., Hurtado, S., \& Gurin, G. (2002). Diversity in higher education: Theory and impact on educational outcomes. Harvard Educational Review, 72, 330-366. https://doi.org/10.17763/haer.72.3.01151786u134n051

Gurin, P., Lehman, J. S., Lewis, E., Dey, E. L., Gurin, G., \& Hurtado, S. (2004). Defending diversity: Affirmative action at the University of Michigan. University of Michigan Press. https://doi.org/10.3998/mpub.17844

Healey, M., Flint, A., \& Harrington, K. (2014). Engagement through partnership: Students as partners in learning and teaching in higher education. Higher Education Academy.

Herrmann, S.D., Adelman, R. M., Bodford, J. E., Graudejus, O., Okun, M.A., \& Kwan, V.S.Y. (2016). The effects of a female role model on academic performance and persistence in women in STEM courses. Basic and Applied Social Psychology, 38(5), 258-268. https://doi.org/10.1080/01973533.2016.1209757

Higher Education Research Institute. (2010). Degrees of success: Bachelor's degree completion rates among initial STEM majors. UCLA. https://heri.ucla.edu/publications/

Hrabowski, F. A. (2019). The empowered university: Shared leadership, culture change, and academic success. Johns Hopkins University Press.

Hudgings, J., \& Dalton, C. (2019, March 26). Out of the margins. Physics World: Diversity and 
Inclusion. https://physicsworld.com/a/out-of-the-margins/

Hussar, W. J., \& Bailey, T. M. (2018). Projections of education statistics to 2026 (45th edition). National Center for Education Statistics.

Jaswal, S. S. (2019). Being human in STEM: Moving from student protest to institutional progress. Association of American Colleges and Universities Diversity and Democracy, 22(1). https://www.aacu.org/diversitydemocracy/2019/winter/iaswal

Kets, W., \& Sandroni, A. (2016). Challenging conformity: A case for diversity. Social Science Research Network. https://doi.org/10.2139/ssrn.2871490

Lambert, N. M., Stillman, T. F., Hicks, J. A., Kamble, S., Baumeister, R. F., \& Fincham, F. D. (2013). To belong is to matter: Sense of belonging enhances meaning in life. Personality and Social Psychology Bulletin, 39(11), 1418-1427. https://doi.org/10.1177\%2F0146167213499186

Matthews, K.E. (2017). Five propositions for genuine students as partners practice. International Journal for Students as Partners, 1(2). https://doi.org/10.15173/ijsap.v1i2.3315

Matthews, K. E., Dwyer, A., Russell, S., \& Enright, E. (2018). It is a complicated thing: Leaders' conceptions of students as partners in the neoliberal university. Studies in Higher Education, 44(12). https://doi.org/10.1080/03075079.2018.1482268

May, G. S., \& Chubin, D. E. (2013). A retrospective on undergraduate engineering success for underrepresented minority students. The Research Journal for Engineering Education, 92(1), 27-39. https://doi.org/10.1002/i.2168-9830.2003.tb00735.x

Mayhew, M. J., Grunwald, H. E., \& Dey, E. L. (2005). Curriculum matters: Creating a positive climate for diversity from the student perspective. Research in Higher Education, 46, 389-412. https://doi.org/10.1007/s11162-005-2967-0

McNair, T. B. (2016). Becoming a student-ready college: A new culture of leadership for student success. Jossey-Bass.

McNamara, M. (2018). Being Human in STEM: The voices of the pioneers. http://www.beinghumaninstem.com/documentary.html

Miller, J. D., \& Kimmell, L. G. (2012). Pathways to a STEMM profession. Peabody Journal of Education, 87(1), 26-45.

National Science Foundation (NSF) and National Center for Science and Engineering Statistics (NCSES). (2019). Women, minorities, and persons with disabilities in science and engineering. Special Report.

Ong, M., Wright, C., Espinosa, L. L., \& Orfield, G. (2011). Inside the double bind: A synthesis of empirical research on undergraduate and graduate women of color in science, technology, engineering, and mathematics. Harvard Educational Review, 81(2), 172208. https://doi.org/10.17763/haer.81.2.t022245n7x4752v2

Penner, M. R. (2018). Building an inclusive classroom. Journal of Undergraduate Neuroscience Education, 16(3), A268-A272.

Reese, A. J. (2020). An undergraduate elective course that introduces topics of diversity, equity,

Bunnell, S.L., Lyster, M.M., Greenland, K.B., Mayer, G., Gardner, K., Leise, T., Kristensen,T., Ryan, E., 55 
and inclusion into discussions of science. Journal of Microbiology \& Biology Education, 21(1). https://doi.org/10.1128/imbe.v21i1.1947

Schneider, C. G. (2014). Making excellence inclusive: Liberal education and America's promise. Liberal Education, 100(4). Association of American Colleges \& Universities. https://www.aacu.org/publications-research/periodicals/making-excellence-inclusive liberal-education-americas-promise

Silber, M. (2018, June 1). Race and gender in the scientific community. SIAM News. https://sinews.siam.org/Details-Page/race-and-gender-in-the-scientific-community

Tanner, K. D. (2013). Structure matters: Twenty-one teaching strategies to promote student engagement and cultivate classroom equity. CBE: Life Sciences Education, 12(3), 322331. https://doi.org/10.1187\%2Fcbe.13-06-0115

Treisman, U. (1992). Studying students studying calculus: A look at the lives of minority mathematics students in college. The College Mathematics Journal, 23(5), 362-372. https://doi.org/10.2307/2686410

Wang, M.-T., \& Degol, J.L. (2017). Gender gap in science, technology, engineering, and mathematics (STEM): Current knowledge, implications for practice, and future directions. Educational Psychology Review, 29(1), 119-140. https://doi.org/10.1007/s10648-015-9355-x

Witham, K., Malcolm-Piqueux, L. E., Dowd, A. C., \& Bensimon, E. M. (2015). America's unmet promise: The imperative for equity in higher education. Association of American Colleges and Universities. 